\title{
Helicobacter pylori enfeksiyonunun D vitamini, hemogram parametreleri ve kan grubu ile ilişkisi
}

\author{
Association of Helicobacter pylori infection with vitamin D, hemogram parameters, and blood group
}

\author{
Ahmet NALBANT ${ }^{1}$, Ayhan AYDIN² \\ ${ }^{1}$ Sakarya Üniversitesi Tıp Fakültesi, İç Hastalıkları Ana Bilim Dalı, Sakarya \\ ${ }^{2}$ Sakarya Üniversitesi Eğitim ve Araştırma Hastanesi, İç Hastalıkları Kliniği, Sakarya
}

\begin{abstract}
Giriş ve Amaç: Helicobacter pylori bölgemizde ve dünyada yüksek prevalansa sahip olup yaygın kronik inflamasyona neden olur. Biz bu çalışmamızda D vitamini, hemogram parametreleri ve kan grupları ile Helicobacter pylori arasında iliş̧i olabileceğini göstermeyi amaçladık. Gereç ve Yöntem: Çalışmaya dispeptik şikâyetlerle iç hastalıkları polikliniğine başvurup endoskopi yapılan ve biyopsi ile Helicobacter pylori tanısı konan 91 hasta alındı. Hastalar Helicobacter pylori pozitif ve negatif olarak $i k i$ gruba ayrıldı. Demografik ve laboratuvar verileri hasta kayıtlarından elde edildi. Bulgular: Hastaların ( $n=91)$ yaş ortalaması $42.5 \pm 13$ yll, 70 (\%76.9)'ı kadın, 21 (\%23.1)'i erkek ve 57 (\%62.6)'si Helicobacter pylori pozitifti. Helicobacter pylori pozitif hastalarla negatif hastalar arasinda yaş, beden kitle indeksi bakımından istatiksel olarak anlamlı fark var$d_{\imath}$ (sirasılyla $P=0.001, P=0.048$ ). Cinsiyet ile Helicobacter pylori arasında ilişki yoktu (Pearson Chi-Square $r=0.186, P=0.663$ ). Helicobacter pylori enfeksiyonu tespit edilen hastalarda kandaki nötrofil, lenfosit sayısında, nötrofil lenfosit oranında belirgin azalma saptanmıştır ancak istatistiksel açıdan sadece nötrofil sayısındaki düşüklük anlamlıdır, sırasıyla ( $P$ $<0.007, P=0.258, P=0.155$ ). Helicobacter pylori tespit edilen hastalar negatif hastalarla karşılaştırıldığında 25-OH D3 düzeyleri düşüktü (Pearson Chi-Square $r=3.95$ and $P=0.047$ ). Helicobacter pylori ile kan grupları ve $R h$ arasinda korelasyon yoktu (sırasıly Pearson Chi-Square $r=6.383$ ve $P=0.094$, Pearson Chi-Square $r=0.131$ ve $P=0.717$ ). Sonuç: Helicobacter pylori pozitif hastalardaki nötrofil sayısı, düşük serum vitamin D düzeyleri ile Helicobacter pylorinin yol açığı kronik inflamasyona bağlı olabilir.
\end{abstract}

Anahtar kelimeler: Helicobacter pylori, D vitamini, hemogram parametreleri, kan grubu

\section{GíRiş}

Helicobacter pylori (H. pylori); kronik gastrit, gastrik ülser, duodenal ülser ve mide kanserinin primer nedeni olarak tanımlanan gram (-) bir bakteridir. H. pylori pozitif hastaların yaklaşık \%10-15'inde peptik ülser, \%1'inde gastrik kanser ya da MALT lenfoma gelişir (1). H. pylori nötrofiller, eozinofiller, lenfositler, plazma hücreleri ve mast hücreleri infiltrasyonuyla gastrik mukoza iltihabına neden olmaktadır $(2,3)$.

Aktif $H$. pylori gastritlerinde mukozadaki mast hücrelerinin, nötrofillerin toplanmasında aktif bir rol aldığı düşünülmüştür $(4,5)$. H. pylori mide mukozasına ulaşınca, epitel hücrelerinin birbirlerine temas ettikleri yerlere yapışır.
Background and Aims: Helicobacter pylori infection is highly prevalent in developing countries, including Turkey, and causes widespread chronic inflammation. We suggest there may be an association between Helicobacter pylori infection and vitamin D, hemogram parameters, and blood group. Methods: In this study, 91 patients presented to an internal medicine outpatient clinic with dyspepsia and were found to have Helicobacter pylori infection by endoscopy. Patients were divided into two groups according to Helicobacter pylori positivity. Demographic and laboratory characteristics were obtained from medical records. Results: Mean age was $42.5 \pm 13$ years; $77 \%$ were women, and $62.6 \%$ were $\mathrm{He}$ licobacter pylori positive. Age and body mass index differed significantly between Helicobacter pylori positive and negative patients $(P=0.001$, $P=0.048$, respectively). There was no association between gender and Helicobacter pylori positivity (Pearson Chi-Square $=0.186, P=0.663$ ). Neutrophil, lymphocyte, and neutrophil lymphocyte ratio were remarkably lower in Helicobacter pylori positive patients but only the reduction in neutrophil counts was statistically significant $(P<0.007, P 0.258$, $P=0.155$, respectively). Levels of 25-OH D3 were lower in patients who were Helicobacter pylori positive compared with those who were negative (Pearson Chi-Square 3.95, $P=0.047$ ). There were no associations between Helicobacter pylori positivity and blood group or Rh status (Pearson Chi-Square $=6.383, P=0.094$; Pearson Chi-Square $=0.131, P=0.717$, respectively). Conclusion: Low neutrophil counts in Helicobacter pylori positive patients might be due to interactions between low vitamin $D$ levels and chronic inflammation caused by Helicobacter pylori.

Key words: Helicobacter pylori, vitamin D, hemogram parameters, blood gr

Serbest kalan bakteriyel antijenler, kemotaksinler ve diğer komponentler özellikle polimorfonükleer lökositler (PMNL) ve makrofajları aktive eder. Mast hücreleri nötrofiller için kemotaktik olan interlökin (IL) 1, IL-6, IL-8 ve tümör nekrozis faktör (TNF) alfa ve beta salgılanır. Helicobacter pylori enfeksiyonunda T lenfositler artar. Aktive edilen T lenfositleri kronik enflamasyonun genişlemesine neden olur (6).

Lökositlerin fonksiyonları başlıca fagositoz ve immün cevaptır. İmmün cevap ise hücresel ve humoral olarak iki grupta incelenmektedir. Asıl fagositik hücreler nötrofiller, monositler ve eozinofillerdir. "İmmünosit" denilen hücreler ise lenfositler ve ondan gelişen plazma hücreleridir (7). 
H. pylori'nin immün süpresyon yaptığı ve bu durumun belki de hastalığın kronik gidişinden sorumlu olabileceği sonucuna varılmıştır (8).

Vitamin D kalsiyum homeostazisi dışında güçlü bir immünomodülatördür. Vitamin D'nin farklı formları T ve B hücre üzerinde immünomodülatör etkisi bulunmaktadır. $D$ vitamini hücresel farklılaşma, proliferasyon and apopitozisi inhibe eder (9). D vitamininin, gastrointestinal sistem, solunum yolu ve genitoüriner sistemin mikroorganizmaların invazyonundan korunması, insan monositlerinde hidrojen peroksit sekresyonunun aktive edilmesi ve oksidatif patlama potansiyelini arttırması, immün hücrelerin yara iyileşmesini sürdürmesi veya enfeksiyonla mücadelesini arttırmada rolü vardır $(10,11)$. D vitamini eksikliğinin otoimmün gastrit ve gastrik kansere predispoze faktör olduğu gösterilmiştir $(12,13)$. H. pylori enfeksiyonu ve D vitamini yetersizliği inflamatuvar sitokinler yoluyla sistemik veya lokal inflamatuvar cevabı uyarabilir.

Kan grubu ile hastalıklar arasında ilk kanıtlanmış ilişki peptik ülser ile 0 kan grubu arasındaki ilişkidir $(14,15)$. $H$. pylori de peptik ülsere neden olmaktadır.

Bu çalışmada $H$. pylori ile hemogram parametreleri, D vitamini ve kan grupları arasında ilişki olabileceği araştırıldı.

\section{GEREÇ ve YÖNTEM}

Çalışmaya Nisan 2016 ve Ekim 2016 tarihleri arasında hastanemiz iç hastalıkları polikliniğine dispeptik şikayetlerle başvurup üst gastrointestinal sistem endoskopileri hastanemiz gastroenteroloji uzmanı tarafından yapılan ve biyopsileri bir patolog tarafından incelenip histopatoloji ile Helicobacter pylori tanısı konulan hastalar alındı. Hastalar $H$. pylori pozitif ve negatif olarak iki gruba ayrıldı. 18 yaşından büyük, D vitamin tedavisi almayan, proton pompası inhibitörü, H. pylori tedavisi ve antibiyotik tedavisi almayan ve gebe olmayan hastalar çalışmaya alındı. Demografik, hemogram parametreleri, C-reaktif protein (CRP), romatoid faktör (RF), prokalsitonin, D vitamini, tiroid stimülan hormon (TSH), anti troglobulin (TG), anti tiroid peroksidaz (TPO), B12 vitamin ve kan grubu verileri hasta kayıtlarından elde edildi. Tıp fakültemizden etik kurul onayı (71522473/050.01.04/80) alındı.

\section{Ölçümler}

Endoskopi Fujinon Tokyo Japan cihazıyla gastroenteroloji uzmanı tarafından yapıldı. Mide antrum ve korpus (küçük ve büyük kurvatur)'undan alınan 2'şer adet biyopsi örneğinin histopatolojik incelemesi giemsa boyama yöntemi ile yapıldı. H. pylori tanısı patoloji uzmanı tarafından kondu. Histopatolojik inceleme $H$. pylori enfeksiyonunun tanısında altın standart olarak kabul edilmektedir (16).
Bu yöntemin duyarlılığı \%93-98, özgüllüğü \%95-98’dir (17).

Euglobulin clot lysis assay (ECLA) kit (Roche, Germany) kullanarak 25-OH D düzeyleri çalışıldı ve endokrin derneği kriterlerine göre ( $\geq 30 \mathrm{ng} / \mathrm{mL}$ ) normal olarak tanımlandı. Hemogram parametreleri (nötrofil, lenfosit, platelet) Celldyn 3700 cihazı ile çalışıldı.

\section{İstatistiksel Değerlendirme}

Verilerin analizi SPSS, version 10.0 [SPSS Inc, Chicago, IL] kullanılarak yapıldı. Tanımlayıcı analiz için ortalama \pm standart deviasyon (SD), grupların karşılaştırılmasında oneway ANOVA analizi ile yapıldı. Gruplar arasında daha ileri analiz için Kruskal Wallis testi kullanıldı. Kategorik değişkenler Pearson Chi-Square ile değerlendirildi. İstatistiksel veriler $\mathrm{P}<0.05$ ise anlamlı kabul edildi.

\section{BULGULAR}

Hastaların ( $n=91$ ) yaş ortalaması $42.5 \pm 12.95$ yıl, kadın sayısı 70 (\%76.9), erkek sayısı 21 (\%23.1) idi. H. pylori pozitif 57 (\%62.6), H. pylori negatif 34 (\%37.4) hasta vardı. İki grubun genel özellikleri ve P değerleri Tablo 1'de verilmiştir. $H$. pylori pozitif hastalarda $H$. pylori negatif hastalara göre yaş, beden kitle indeksi (BKi) ve nötrofil sayısı arasında istatiksel olarak anlamlı fark vardı (sırasıyla $P=0.001, P=0.048, P=0.007$ ) (Şekil 1). Serum 25-OH düzeylerinin aylara göre dağılımı ANOVA ile karşılaştırıldığında arada anlamlı fark olmadığı görüldü ( $F=1.661$, $\mathrm{P}=0.143)$. D vitamini eksikliği $H$. pylori pozitif hastalarda H. pylori negatif hastalara göre anlamlı derecede daha fazlaydı (Pearson Chi-square $r=3.95 ; \mathrm{P}=0.047$ ). H. pylori pozitif hastalarda negatif hastalara göre lenfosit, monosit, platelet, nötrofil lenfosit oranı (NLR), platelet lenfosit oranı (PLR), hemoglobin, B12 vitamini, ferritin, CRP, RF ve prokalsitonin, TSH, anti TPO ve anti TG düzeyleri arasında istatistiksel olarak anlamlı ilişki yoktu ( $P>0.05)$. Cinsiyet ile H. pylori arasında korelasyon yoktu (Pearson Chi-Square $r=0.186, P=0.663)$. $H$. pylori aktivasyonu 0 dan 3'e kadar kategorize edildiğinde sırasıyla aktivasyonu sıfır olan hasta sayısı 34, bir olan 31, iki olan 15, üç olan 11 hasta mevcuttu. 4 grup arasında nötrofil sayısı için ANOVA ile $(P=0.041)$ istatiksel olarak anlamlı fark bulundu.

91 hastanın 41'i 0 grup, 40' । grubu, 6'sı AB grubu, 4'ü B kan grubuna sahipti. 84 hasta Rh $(+)^{\prime}$ ti. 0 kan grubu olan 41 hastanın 21'i, A kan grubu olan 40 hastanın 28'i, B kan grubu olan 4 hastanın 3'ü, AB kan grubu olan 6 hastanın 5'i H. pylori pozitifti. H. pylori pozitif hasta en çok A kan grubundaydı (\%49). H. pylori pozitif hastaların \%91'i Rh (+) idi. H. pylori ile kan grupları arasında korelasyon yoktu (Pearson Chi-Square $r=6.383$ ve $P=0.094$ ). H. pylori ile Rh arasında da korelasyon yoktu (Pearson Chi-Square $\mathrm{r}=0.131$ ve $\mathrm{P}=0.717$ ) (Tablo 2). 
Tablo 1. H. pylori pozitif ve $H$. pylori negatif hastaların genel özellikleri ve P değerleri.

\begin{tabular}{|c|c|c|c|}
\hline & H. pylori pozitif (n: 57) & H. pylori negatif (n: 34) & $\mathbf{P}$ \\
\hline Yaş (yıl) (SD) & $39.21 \pm 12.19$ & $48.21 \pm 12.38$ & 0.001 \\
\hline $\mathrm{BKI}\left(\mathrm{kg} / \mathrm{m}^{2}\right)(\mathrm{SD})$ & $25.28 \pm 4.4$ & $27.35 \pm 5.3$ & 0.048 \\
\hline$D$ vit $(n g / m L)(S D)$ & $15.4 \pm 6.7$ & $18.2 \pm 7.4$ & 0.047 \\
\hline Nötrofil $\left(\mathrm{K} / \mathrm{mm}^{3}\right)(\mathrm{SD})$ & $3.6 \pm 1.1$ & $4.5 \pm 1.9$ & 0.007 \\
\hline Lenfosit $\left(\mathrm{K} / \mathrm{mm}^{3}\right)(\mathrm{SD})$ & $2.1 \pm 0.6$ & $2.3 \pm 0.6$ & 0.258 \\
\hline Monosit $\left(\mathrm{K} / \mathrm{mm}^{3}\right)(\mathrm{SD})$ & $0.50 \pm 0.15$ & $0.48 \pm 0.18$ & 0.658 \\
\hline $\mathrm{Plt}\left(\mathrm{K} / \mathrm{mm}^{3}\right)(\mathrm{SD})$ & $261.61 \pm 63.7$ & $286.13 \pm 70.1$ & 0.097 \\
\hline $\mathrm{Hgb}(\mathrm{gr} / \mathrm{dl})(\mathrm{SD})$ & $13.0 \pm 1.6$ & $12.6 \pm 1.6$ & 0.292 \\
\hline PLR (SD) & $128.35 \pm 48.1$ & $131.08 \pm 55.8$ & 0.809 \\
\hline $\mathrm{NLR}(\mathrm{IQR})$ & $1.8(0.8)$ & $2.0(1.3)$ & 0.155 \\
\hline $\operatorname{CRP}(\mathrm{mg} / \mathrm{L})(\mathrm{IQR})$ & $3.2(1.1)$ & $3.1(0.8)$ & 0.307 \\
\hline $\mathrm{RF}(\mathrm{IU} / \mathrm{mL})(\mathrm{IQR})$ & $9.6(2.0)$ & $9.6(0.5)$ & 0.485 \\
\hline Prokalsitonin (ng/mL) (IQR) & $0.05(0)$ & $0.05(0)$ & 0.232 \\
\hline $\mathrm{TSH}(\mathrm{IU} / \mathrm{dL})(\mathrm{SD})$ & $1.24 \pm 0.6$ & $1.63 \pm 1.3$ & 0.113 \\
\hline Anti TG (IU/mL) (IQR) & $1(13.5)$ & $1.9(15.3)$ & 0.696 \\
\hline Anti TPO (IU/mL) (IQR) & $0.46(1.3)$ & $1.0(43.9)$ & 0.672 \\
\hline $\mathrm{B} 12$ vit $(\mathrm{pg} / \mathrm{ml})(\mathrm{IQR})$ & $159(152)$ & $205.5(129)$ & 0.831 \\
\hline Folat (ng/mL) (SD) & $5.8 \pm 2$ & $5.5 \pm 2$ & 0.681 \\
\hline Ferritin $(\mathrm{ng} / \mathrm{mL}) \quad(\mathrm{IQR})$ & $17.7(17)$ & $15.9(28)$ & 0.666 \\
\hline Kadın (n: 70) & 43 & 27 & \\
\hline Erkek (n: 21) & 14 & 7 & \\
\hline
\end{tabular}

SD: Standart sapma. BKi: Beden kitle indeksi. Plt: Platelet. Hgb: Hemoglobin. PLR: Platelet lenfosit oranı. NLR: Nötrofil lökosit oranı. CRP: C-reaktif protein. RF: Romatoid faktör. TSH: Tiroid stimulan hormon. Anti TG: Anti triglobulin. Anti TPO: Anti tiroid peroksidaz.

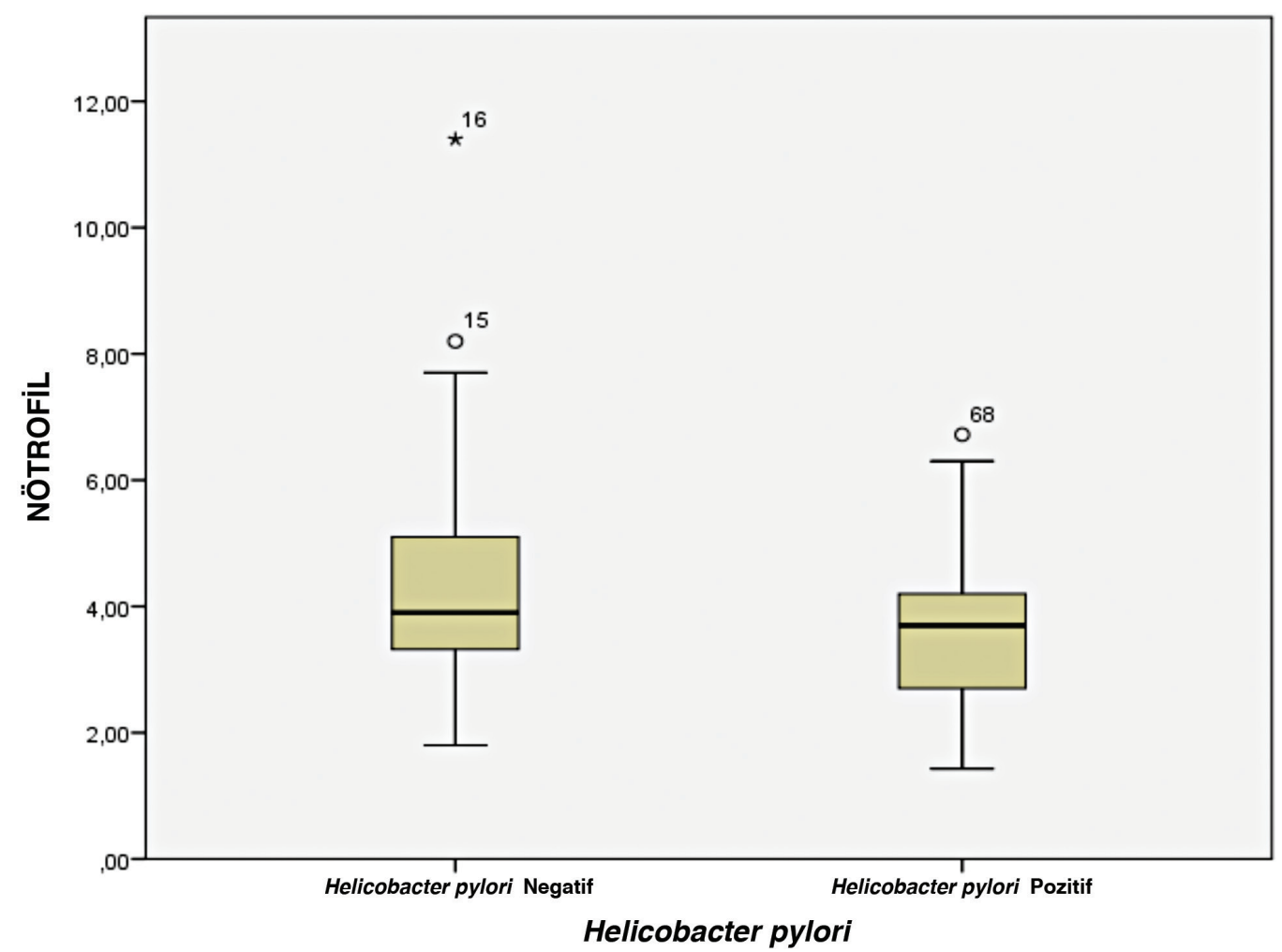

Şekil 1. H. pylori pozitif ve negatif hastaların nötrofil sayısının grafiksel görünümü. 


Tablo 2. H. pylori ile kan grupları ve Rh dağılımı
\begin{tabular}{|c|c|c|c|c|c|c|}
\hline 0 grubu (n: 41) & A grubu (n: 40) & B grubu (n: 4) & AB grubu (n: 6) & Rh (+) (n: 84) & Rh (-) (n :7) \\
\hline Hp pozitif (n:57) & $21(\% 37)$ & $28(\% 49)$ & $3(\% 5)$ & $5(\% 9)$ & $52(\% 91)$ & $5(\% 9)$ \\
\hline Hp negatif (n:34) & $20(\% 58)$ & $12(\% 36)$ & $1(\% 3)$ & $1(\% 3)$ & $32(\% 94)$ & $2(\% 6)$
\end{tabular}

Hp pozitif: Helicobacter pylori pozitif

\section{TARTIŞMA}

Dispeptik şikayetlerle ayaktan başvuran ve endoskopik tetkikle değerlendirilen 91 hastanın incelendiği bu çalışmada, $H$. pylori pozitif olan hastalarda negatif olanlara göre BKi ve nötrofil sayısı anlamlı derecede düşük olarak bulundu. Ayrıca D vitamini yetersizliğinin H. pylori pozitif hastalarda negatiflere göre daha fazla olduğu gözlendi. Kan grupları ile $H$. pylori durumu arasında ise ilişki saptanmadı.

D vitamini, H. pylori enfeksiyonundaki inflamasyonun kontrolünde önemlidir. Aktif D vitamini kullanımı ile $H$. pylori enfeksiyonlarında \%50'den fazla azalma çalışmalarda gösterilmiştir (18). Çin'de yapılan bir çalışmada D vitamini reseptörlerinin gastrik mukoza hemoostazisinde rol aldığı ve $H$. pylori enfeksiyonundan koruyucu etki yaptığı gösterilmiştir (12). Başka bir çalışmada diyalize giren kronik böbrek yetmezliği hastalarında 25-OH D3 vitamini ile H. pylori spesifik immünglobulin (lg) G antikor titreleri arasında pozitif korelasyon vardı (19). İtalya'da yapılan bir çalışmada $H$. pylori'li hastalarda düşük $D$ vitamini bulunmuştur (20). D vitamini eksikliği otoimmün gastrit ve mide kanserine predispoze faktördür $(12,13)$. Biz çalışmamızda $H$. pylori pozitif hastalarda $D$ vitamini düzeylerini H. pylori negatif hastalara göre istatistiksel olarak anlamlı düşük bulduk.

Çalışmamızda H. pylori pozitif hastalarda lökosit (nötrofil, lenfosit) değerlerini düşük ancak nötrofil sayısındaki düşüklüğü istatistiksel olarak anlamlı bulduk. Nötrofil sayısındaki anlamlılık H. pylori enfeksiyon aktivitesi O'dan 3'e kadar ayrıldığında da devam ediyordu. H. pylori pozitif hastalarda monosit sayısı hafif artmış ancak istatistiksel olarak anlamlı fark yoktu. İnflamasyon belirteçlerinden olan NLR H. pylori pozitif hastalarda düşük bulundu. Ülkemizde yapılan bir çalışmada $H$. pylori pozitif kişilerde kandaki lökosit (nötrofil, lenfosit, monosit) sayısında belirgin azalma saptanmış ancak istatistiksel açıdan sadece kadınlardaki monosit sayı değişikliğinin önemli olduğu görülmüştür (21).

Knipp U ve arkadaşlarının yaptığı çalışmada $H$. pylori pozitif grupta lenfosit ve bazofil sayısındaki yükseklik istatistiksel açıdan anlamlı bulunmuştur. H. pylori negatif grupta tüm lökosit değerleri yüksek bulunmuş ancak bun- lardan sadece monosit sayısındaki yükseklik istatistiksel açıdan anlamlılık göstermiştir. H. pylori'nin immünsüpresyon yaptığı ve bu durumun belki de hastalığın kronik gidişinden sorumlu olabileceği sonucuna varılmıştır (8). Literatürde $H$. pylori'nin idiyopatik immün trombositopeni ve demir eksikliği ile birlikte olduğu gösterilmiştir $(22,23)$. H. pylori pozitif grupta platelet sayısı ve PLR düşük olmasına rağmen istiksel olarak anlamlılık bulamadık. Hemoglobin ve ferritin değerleri arasında da fark yoktu.

Obezite ile $H$. pylori arasındaki ilişki konusunda yapılan çalışmalar bugün için oldukça az sayıda ve çelişkilidir. On sekiz gözlemsel çalışmayı içeren bir meta-analizde H. pylori negatif vakalara göre $H$. pylori pozitif vakalarda daha yüksek BKi değerleri bulunmuştur (24). Aksine, Ioannou ve arkadaşları $H$. pylori seropozitifliği ile BKI arasındaki ilişki konusunda yaptıkları çalışmada $H$. pylori seropozitivitesi veya $H$. pylori virülans faktör (Cag A-cytotoxin associated gene A) antikor düzeyinin BKi ile ilişkili olmadığı sonucuna vardılar (25). Ülkemizde BKI dikkate alınarak yapılan bir çalışmada gruplar arasında $H$. pylori pozitifliği yönünden anlamlı fark bulunmamıştır (26). Bizim çalışmamıda istatiksel olarak $H$. pylori pozitif hastalarda BKi anlamlı derecede düşük bulunmuştur.

Çalışmamızda obeziteyi etkileyeceği düşünülerek H. pylori pozitif hastalarda bakılan TSH, anti TG, anti TPO değerleri, H. pylori negatif hastalara göre düşük bulundu ama istatistiksel olarak anlamlı fark yoktu.

Kan grubu ile hastalıklar arasında ilk kanıtlanmış ilişki peptik ülser ile 0 kan grubu arasındaki ilişkidir $(14,15)$. $H$. pylori peptik ülser ve gastrik kansere yol açar. $H$. pylori dünya nüfusunun yaklaşık yarısında midede kolonizedir (27). Milorad ve arkadaşları kan grupları ve Rh pozitifliklerini dikkate alarak yaptıkları çalışmada gruplar arasında $H$. pylori sıklığı yönünden istatistiksel olarak anlamlı farklılık saptamadılar (28). Bizim çalışmamızda en fazla gözlenen kan grubu A kan grubundaydı (\%49). H. pylori pozitif hastaların \%91'i Rh pozitif idi. H. pylori pozitifliği ile kan grupları ve Rh pozitifliği arasında ilişki yoktu.

H. pylori pozitif bireylerde CRP'nin arttığı bildirilmiştir $(29,30)$. Çalışmamızda CRP, RF, prokalsitonin düzeylerini 
düşük bulduk ancak istatiksel anlamlılık yoktu. Bunun yanı sıra, H. pylori pozitif bireylerde B12 vitamininin azaldığı belirtilmektedir (31). Çalışmamızda B12 düzeyleri normaldi.

D vitamin yetersizliği ve nötrofil sayısında azalma $H$. pylori pozitifliği olan hastalarda daha fazla tespit edilmiştir. $H$. pylori immün sistemi aktive etmenin yanında aktive olmuş hücreleri regüle ederek immün süpresyon yaptığı için nötrofil sayısı düşük bulunmuş ve immün modülatör olan 25-OH D3 düşüklüğü bu durumu etkilemiş olabilir.

Sonuç olarak H. pylori enfeksiyonu pozitif hastalarda 25OH D3 düşüklüğü riskinin göz önüne alınması bu hastaların takibinde önemli olabilir.

\section{KAYNAKLAR}

1. Liou J-M, Lin J-T, Lee Y-C, et al. Helicobacter pylori infection in the elderly. Int J Geront 2008;2:145-53.

2. Theoharides TC, Cochrane DE. Critical role of mast cells in inflammatory diseases and the effect of acute stres. I Neuroimmunol 2004;146:1-12.

3. Nakajima S, Krishnan $B$, Ota $\mathrm{H}$, et al. Mast cell involvement in gastritis with or withouth Helicobacter pylori infection. Gastroenterology 1997;113:746-54.

4. Nakajima S, Graham DY, Hattori T, Bamba T. Strategy for treatment of Helicobacter pylori infection in adults. I. Updated indications for test and eradication therapy suggested in 2000. Curr Pharm Des 2000;6:1503-14.

5. Gionchetti $P$, Vaira D, Campieri $M$, et al. Enhanced mucosal Interleukin 6 and 8 in Helicobacter pylori-positive dyspeptic patients. Am J Gastroenterol 1994;89:883-7.

6. Brooks GF, Janet SB, Stephen AM. Jawetz M. Melinck\&Adelberg's Medical Microbiology, 21. Appleton \& Lange, Connecticut, s:2423;1995.

7. Dunn BE. Pathogenic mechanisms of Helicobacter pylori. Gastroenterol Clin North Am 1993;22:43-57.

8. Knipp U, Birkholz S, Kaup W, Opferkuch W. Immune supressive effects of Helicobacter pylori on human peripheral blood mononuclear cells. Med Microbiol Immunol 1993;182:63-76.

9. Mansournia N, Mansournia MA, Saeedi S, Dehghan J. The association between serum 25OHD levels and hypothyroid Hashimoto's thyroiditis. J Endocrinol Invest 2014;37:473-6.

10. Yamshchikov AV1, Desai NS, Blumberg HM, et al. Vitamin D for treatment and prevention of et al infectious diseases: A systematic review of randomized controlled trials. Endocr Pract 2009;15:438-49.

11. Von Essen MR, Kongsback M, Schjerling P, et al. Vitamin D controls $T$ cell antigen receptor signaling and activation of human $T$ cells. Nat Immunol 2010;11: 344-9.

12. Guo L, Chen W, Zhu H, et al. Helicobacter pylori induces increased expression of the vitamin $\mathrm{D}$ receptor in immune responses. Helicobacter 2013;19:37-47.

13. Bao A, Li Y, Tong Y, et al. Tumor suppressive effects of 1.25-dihydroxiyvitamin D3 in gastric cancer cells. Hepatogastroenterology 2013;60:943-8.

14. Braden B, Caspary WF. Detection of Helicobacter pylori infection: when to perform which test? Ann Med 2001;33:91-7.

15. El-Zimaity HM, Graham DY, al-Assi MT, et al. Interobserver variation in the histopathologic assessment of Helicobacter pylori gastritis. Human Pathol 1996;27:35-41.

16. Kawaura A. Inhibitory effect of long term 1 alpha-hydroxyvitamin D3 administration on Helicobacter pylori infection. J Clin Biochem Nutr 2006;38:103-6.

17. Nasri H, Baradaran A. The influence of serum 25-hydroxy vitamin D levels on Helicobacter pylori Infections in patients with end-stage renal failure on regular hemodialysis. Saudi J Kidney Dis Transpl 2007;18:215-9.

18. Antico A, Tozzoli R, Giavarina D, et al. Hypovitaminosis D as predisposing factor for atrophic type A gastritis: a case-control study and review of the literature on the interaction of vitamin $D$ with the immune system. Clin Rev Allergy Immunol 2012;42:355-64.

19. Telatar B, Bayramiçli OU, Kılıç D, et al. Helicobacter pylori enfeksiyonunun kan lökositlerinde oluşturduğu sayısal değişiklikler. KEAH Tıp Dergisi 1997;8:1-4.

20. Stasi R, Sarpatwari A, Segal JB, et al. Effects of eradication of Helicobacter pylori infection in patients with immune trombocytopenic purpura: a systemic review. Blood 2009;113:1231-40.

21. Huang $X, Q u X$, Yan $W$, et al. Iron deficiency anemia can be improved after eradication of Helicobacter pylori. Postgrad Med J 2010;86:272-8.

22. Boltin D, Niv Y. Ghrelin, Helicobacter pylori and body mass: is there an association? Isr Med Assoc J 2012; 14: 130-2.

23. Ioannou GN, Weiss NS, Kearney DJ. Is Helicobacter pylori seropositivity related to body mass index in the United States? Aliment Pharmacol Ther 2005;21:765-72.

24. Korkmaz M, Sadıç M, Koca G, ve ark. The relationship of Helicobacter pylori infection with demographic, socio economic and environmental factors: Ankara hospital experience. Kafkas J Med Sci 2013;3:74-9.

25. Aird I, Bentall HH, Mehigan JA, Roberts JA. The blood groups in relation to peptic ulceration and carcinoma of the colon, rectum, breast and bronchus. Br Med J 1954;2:315-21.

26. Clarke CA, Cowan WK, Edwards JW, et al. The relationship of $A B O$ blood groups to duodenal and gastric ulceration. Br Med J 1955;2:643-6.

27. Boren T, Falk P, Roth KA, et al. Attachment of Helicobacter pylori to human gastric epithelium mediated by blood group antigens. Science 1993;262:1892-5.

28. Petrović M, Artiko V, Novosel S, et al. Relationship between Helicobacter pylori infection estimated by 14C-urea breath test and gender, blood groups and Rhesus factor. Hell J Nucl Med 2011;14:214.

29. Stettin D, Waldmann A, Ströhle A, et al. Association between Helicobacter pylori-infection, C-reactive protein and status of B vitamins. Adv Med Sci 2008;53:205-13.

30. Jafarzadeh A, Hassanshahi GH, Nemati M. Serum levels of high-sensitivity C-reactive protein (hs-CRP) in Helicobacter pylori-infected peptic ulcer patients and its association with bacterial Cag A virulence factor. Dig Dis Sci 2009;54:2612-6.

31. Serin E, Gümürdülü $Y$, Ozer B, et al. Impact of Helicobacter pylori on the development of vitamin B12 deficiency in the absence of gastric atrophy. Helicobacter 2002;7:337-41. 